Journal of Social Sciences 6 (2): 229-233, 2010

ISSN 1549-3652

(C) 2010 Science Publications

\title{
Secularism and Theism: A Problem of Rationality
}

\author{
Michael Roess \\ Department of Philosophy, Stony Brook University, SUNY at Stony Brook, \\ Harriman Hall 213, Stony Brook, NY 11794 United States
}

\begin{abstract}
Problem statement: A belief prevails today that pluralist liberal societies and genuine religious belief are incompatible. Until this belief is overcome it is unlikely that progress can be made toward dialogue between liberal pluralists, who pride themselves on their open-mindedness and rationality, and religious conservatives in America and theocrats elsewhere who esteem their devotion equally highly. Approach: Compare the rationality of "paradigm shifts" and that of religious conversion. Results: There was no difference in rationality between scientific progress when understood as a "paradigm shift" and that between conversion from theism to atheism or vice versa. Conclusion: Neither secularists nor theists were justified in their belief that liberalism and theism are incompatible. Pluralities of beliefs are all equally justifiable in terms of reason.
\end{abstract}

Key words: Liberalism, rationality, religion, secularism, conversion

\section{INTRODUCTION}

A belief prevails today that pluralist liberal societies and genuine religious belief are incompatible. If we wish to draw crude sides in the disagreementliberals and religious conservatives-we can see that members of both parties share this belief. On the one hand, certain theocracies ban all artifacts of "western culture" even when they are not obviously forbidden by Islamic law. Likewise, religious conservatives in America have also turned "liberal" into a term of contempt. On the other hand the French are pushing to outlaw the Burka.

At the root of this dispute is a conviction that "reason" is incompatible with belief in many religious dogmas. This claim undergirds the liberal theories of even those most sympathetic toward religion such as Rawls (2005; 1997), who seeks to permit a pluralism of "reasonable" religions. Until this belief in the incompatibility of liberalism and religious belief is addressed it is unlikely that progress can be made toward dialogue between liberal pluralists, who pride themselves on their open-mindedness and rationality, and Islamic theocrats and religious conservatives in America who esteem their devotion equally highly. To that end, then, I hope to propose a conception of rationality that is compatible with both scientific and religious belief (In this I am closely following the work of Van Fraassen (2002). This study can be seen as an extension of that work to address political problems. For more on Van Fraassen's work I direct the reader to Van Fraassen, 2002).
In order to do this, I explain Bas Van Fraassen's discussion of "conceptual revolutions" in The Empirical Stance and apply his criteria for their existence to the fictional conversion of Zosima in Dostoevsky et al. (2002) The Brothers Karamazov. After showing that this conversion fits Van Fraassen's profile of a rationally acceptable conceptual revolution I will argue that such conversions from atheism to theism or vice versa can be reasonable in exactly the same way that the scientific progress they laude is. I will then argue that if this conception of rationality is accurate the alleged moral bankruptcy of pluralist societies can, in fact, foster conversion to a morally focused religion. I conclude by arguing that nothing about a conception of rationality that accepts political pluralism is inherently productive or destructive to either atheism or theism, Islamic or otherwise.

Conceptual revolutions: Before discussing the special case of conversion I need to spend some time dealing with the epistemological problems presented by "conceptual revolutions" in general. Instances of such revolutions abound in the history of science, and those discussing these changes have made various claims about how they are best understood. I will not here enter into this discussion, but simply adopt the analysis given by Van Fraassen (2002). He describes such changes as having four essential characteristics. First, one set of theoretical beliefs is abandoned for another, and second, both the temporally prior and temporally posterior are, to some extent, comparable. Taken together, these can be called the characteristics of 
comparable belief change. Third, from the perspective of the prior, the posterior is absurd, and fourth from the perspective of the posterior the prior is comprehensible as an error. Taken together these two can be called the characteristics of perspectival asymmetry.

If at least some of the changes in our intellectual history can be rightfully characterized as having such asymmetry, we are confronted with two major epistemological difficulties. Assuming rationality is an essential component to all warranted changes in belief, how can the adoption of what was once regarded as an absurd belief, however beneficial it turns out to be, ever be rational? It is important to note here that, from the position of the prior perspective, the awareness that one's beliefs include an error is simply unavailable, regardless of how clear it is from the posterior position. Without appealing to some fantastic meta-view that can evaluate and compare various perspectives outside of any set of beliefs, it seems that a rational sanction for such a change in view does not exist. This problem leads to a crisis in confidence regarding our present beliefs. If a past irrational change was necessary in order to uncover the error of my former beliefs, might some present error persist that can be understood only through some seemingly irrational change? I will later show how some religious conversions are accurately described by these four conditions, but let us first see how Van Fraassen deals with these problems in the domain of scientific belief.

From rationality to reasonableness: Van Fraassen's answer involves expanding our understanding of warranted epistemological practice. Let's first sketch how we traditionally conceive of normal epistemological practices. We start with some accepted data set from which obvious beliefs are immediately derived, something like "normal experience of the world" for example. Right now I see twenty people in this room and so I am warranted in my belief that there are twenty other people in the room. This set will exclude things like experiences under the influence of hallucinogens and scripturally reported but miraculous occurrences (whose very existence presents hermeneutic problems that we will for the time being ignore). We add to this set certain rules for belief transformation: induction, deduction, abduction etc. Any transformation of the beliefs generated by the original data set performed according to these rules will yield additional beliefs that are rationally warranted. So, for example, I have been outside a number of times when it has been raining, and each time I got wet. I perform the rule sanctioned action "induction" on my beliefs "I got wet when outside in the rain at times $T_{1}$ through $\mathrm{T}_{\mathrm{n}}$," and generate the new rationally warranted belief: whenever I stand outside in the rain I will get wet. Any proper application of these rules will generate rationally acceptable beliefs, and the acceptance of many beliefs generated by the proper application of these rules is rationally compelled. I am thus irrational if, despite overwhelming evidence to the contrary, I believe that the next time I walk out in the rain I will not get wet. Furthermore, all beliefs that are not generated by the original data set or through the rule governed operations performed on this set are irrational.

This is an oversimplification to be sure. There can be arguments over which rules are licit in which circumstances, what counts as the original data set, and so forth. However, this sketch captures one essential feature: knowledge claims must be justified by reference to a set of data that is in principle accessible to anyone and by rules that all agents can and must follow. This is, in a nutshell, the triumph of Enlightenment rationalists over religious dogmatists lauded by the so-called "New Atheists"-Dawkins, Dennett, Hitchens and Harris.

Van Fraassen hopes to replace this conception of rationality with one that he characterizes as "bridled irrationality." Among the various arguments he employs, we will focus on those he makes against the claim that these rules can ever be "value free." If we are forced to admit values in warranted belief generating process, then maybe there is some room for different people holding different beliefs about the same phenomena.

Epistemic values: In order to expand the traditional conception of rationality, Van Fraassen points out that our belief generating activity, like all activity, is guided by some value-implying end. The two most obvious and least controversial of these ends are the avoidance of holding untrue beliefs, on the one hand, and the holding of all "relevantly" true beliefs, on the other. Although there is nothing in principle preventing our holding all and only true beliefs (aside from our limited mental capacity) in practice the degree to which we seek one end we are limited in our pursuit of the other. How, then, do we determine the appropriate "balance" of these competing ends? Usually our practical concerns make this a fairly simple task. When planning a trip to the movies to see A Simple Man, for example, I need to know: what time the movie is playing (but not to the nano-second), if the movie is going to draw a large crowd, if the person I am going with is consistently late.

There are, furthermore, situations in which multiple beliefs, resultant from various rule-governed 
activity of equally rational permissibility, are available. It is common practice to appeal to "aesthetic" values in order to decide between beliefs in these circumstances. Hence the discussion of "elegance" in mathematics and "Ockham's Razor" in physics. When distinguishing between theoretical explanations of the same "data" set, such criteria inevitably creep in to the extent that we diminish the desire to "avoid error" for the sake of "holding true beliefs." Of course a thoroughgoing skeptic need not accept the inclusion of such values, but if we are not to renounce all of our beliefs then it would behoove us to acknowledge them.

Perhaps these values will help better understand the apparent irrationalism of conceptual revolutions and in turn religious conversion. If they are to do this, we must determine when appealing to values is appropriate. It seems uncontroversial to claim that, under circumstances in which these values are acceptable criteria for belief discrimination (not generation) beliefs held by these criteria are neither rationally compelled nor unreasonable held. The traditional epistemologist can accept this claim and simply deny the existence of any such circumstances. What, then, would such circumstances look like? It appears to me that two criteria must be met: The true belief cannot be determined rationally, yet the choice between the two must be forced. Let us examine these in some detail (The debt here to William James's discussion in "The Will to Believe" is noted by Van Fraassen (2002). Although James includes a third criteria, that of a 'live option,' I have omitted it since one cannot have a forced choice between any but two live options).

The choice between beliefs must not be decided by any of the traditionally accepted rules for belief generation. An outlandish example of such a situation might be something like the choice between the beliefs that there are ten or zero invisible elephants in this room fighting to the death. The very insensibility of these elephants guarantees their absence from the original data set in such a way that any belief about their number can be neither rationally compelled nor rationally forbidden. This is all well and good, the traditionalist will say, but we can simply be agnostic in this case. The very same condition that guarantees that the proper belief cannot be rationally compelled also permits an indefinite deferral of the choice.

The second criteria, then, is that the choice be forced. Certainly plenty of choices are forced. Each morning I can either remain in bed or get out. Many action heroes are forced to save the person they love, or one of "great importance." These are choices of action, however, and do not entail a belief that their action will result in success. I may lie in bed only to feel such guilt at not getting up that I am unable to rest. Hope that one's actions will have the desired outcome is certainly not a licit ground for belief that they will. If we can dissociate our beliefs from our actions, then, it seems that a choice between rationally open beliefs is never forced.

Is it always possible to dissociate action and belief? It turns out that it is not in precisely those circumstances where the beliefs to be chosen between are those "theoretical beliefs" which allow us to understand the circumstance in which we find ourselves-enabling action in the first place. Imagine a strict behaviorist who does not believe in "mental entities" such as "ill will." The related notions of guilt and responsibility will have no import for her understanding of a circumstance in which one person harms another. This does not mean that she cannot advocate a jail-term for those who perform harminducing actions, but it does mean that she cannot advocate this jail-term as punishment for ill will, but only for the sake of deterrence or rehabilitation.

Now, if a circumstance demands action of any sort, then some rationally open choice between ways of understanding the circumstance itself may be practically forced. In these circumstances different values, fidelity to perceived experience or consistence with accepted science, must be invoked in order to make a choice. Furthermore, since we are forced to act, agnosticism is not an option.

The question we must now ask ourselves is, once we have already adopted certain foundational beliefs, when is it reasonably permissible to abandon those beliefs for others? Precisely in those circumstances in which the understanding of the situations in which we find ourselves are "unsatisfactory." Since I'm running out of time, I'll have to leave us with this unsatisfying description of these circumstances and merely point to examples of such "unsatisfactory" understandings, such as the plethora of epicycles needed to preserve the circular motion of the heavenly bodies in astronomy, and the existence of horrendous evils that challenge religion.

Religious conversion as conceptual revolution: We have now identified situations in which we may, with warrant, adopt and renounce foundational beliefs without being rationally compelled to so do. As Van Fraassen (2002) points out, this discovery allows us to understand how "conceptual revolutions". In the history of science can be considered reasonable. Let's now examine whether some religious conversions can be understood as similarly revolutionary, and if so whether they are reasonable in the same way. In order to do this, 
I will examine the conversion of Zosima in Dostoevsky's The Brothers Karamazov. Let us first see if Zosima's conversion possesses the four characteristics of conceptual revolutions. There is certainly a comparable change in belief. Zosima renounces his belief that he is justified in having Afanasy serve him. Perhaps more importantly, there has been a clear change in certain foundational beliefs. His changed conception of human dignity explains not only his new beliefs about the inappropriateness of human servitude, but also his beliefs in the nature of responsibility. So much for the comparable transition, but what about the conditions of asymmetry?

The absurdity of his new beliefs from the "perspective" of those he previously held is clearly attested to in at least two instances. Zosima understood his brother's conversion, one similar to his own, as a madness explicable only as material illness. Furthermore, the accusations made against him by his comrades, who held beliefs similar to his prior to conversion, that he was either "mad" or a coward for having thrown his gun into a tree indicate that the beliefs underlying such an action must be absurd.

And what of the intelligibility of his prior beliefs from the point of view of the posterior? The following speech, made in response to the accusation of his comrades, attests to this final condition:

"Yesterday I was still a fool, but today I've grown wiser [...] I ought to have confessed as soon as we arrived here, even before his shot, without leading him into great and mortal sin, but we have arranged everything in the world so repugnantly that to do so was nearly impossible, for only now that I have stood up to his shot from twelve paces can my words mean something for him, but had I done it before his shot, as soon as we arrived, then people should simply say" he's a coward, he's afraid of a pistol, there's no point in listening to him (Dostoevsky et al., 2002). For the complete context, see Book Six, Chapter 2 of this study.)"

If these four characteristics are sufficient conditions for a "paradigm shift" then we clearly have one on our hands. We are now in a position to evaluate the reasonableness of this shift.

Reasonableness of religious conversion: If we are to understand Zosima's conversion as reasonable, then we must identify the "unsatisfactory" understanding of the world in which he lived and the "foundational belief (s)" that lead to them. Whatever beliefs regarding religion Zosima had prior to his conversion, we can point to several results they generated which can only be considered unsatisfying. Not only had he failed to win the girl of his fancy, he was humiliated upon discovering that she had been engaged the entire duration of his infatuation with her. After striking his servant in the face in an attempt to "blow off" his anger he felt not relief, but "something, as it were, mean and shameful in (his) soul." Each of these circumstances has to do, in some respect, with the idea of human dignity and worth. Although he could have continued to maintain his conception of human dignity as it was, in order to do so would have required him to ignore the bloodied face of his servant and attempt to kill a man who brought happiness to a woman he loved. Such actions seem at least as unsatisfying as the invention of epicycles to correct for observations of the heavenly bodies.

As Van Fraassen points out, however, one cannot renounce a belief, no matter how unsatisfying, if there is no known alternative. This is particularly true in the case of "foundational beliefs" about which we cannot be agnostic since they enable us to understand our experiences. From what we know of Zosima's life, the religious alternative espoused by his brother was the only viable alternative for him. His new belief allowed him to better deal with his servant and former love, without eliminating his ability to deal with his former comrades, who accepted his desire to become a monk. The conversion, then, allowed him to deal with other humans as well or better than his prior belief, even if from the perspective of that prior belief, it seemed absurd to accept responsibility for all one's fellow humans.

\section{CONCLUSION}

If this is an adequate examination, then it appears that religious conversion, from atheism to theism or vice versa, can be reasonable. The asymmetry need not privilege one set of beliefs over another absolutely, but only in relation to the set of experiences with which one is confronted. Problems such as the suffering brought about in the name of religious through war, or priestly abuse can lead to as unsatisfactory an understanding for the world as the feelings of loneliness or meaninglessness that often occur in western culture. It should be noted here that a pluralist society facilitates both reasonable conversion, insofar as it makes apparent the options one has for dealing with "unsatisfying" results of one's current conceptual scheme, and the reasonableness of religion, insofar as 
those religious beliefs that produce unsatisfying results for the believer will be abandoned for those that produce more satisfying results. Liberal pluralism, it would seem, neither favors atheism nor condemns theism. To this extent devout Islamists ought neither fear nor condemn liberal societies-which may promote their acceptance-and belligerent atheists ought not condemn religious folk as irrational. Neither of these views are warranted by an accurate conception of rationality.

\section{REFERENCES}

Dostoevsky, F., R. Pevear and L. Volokhonsky, 2002. The Brothers Karamazov. Farrar, Straus and Giroux, New York, ISBN: 0374528373.

Rawls, J., 2005. Political Liberalism. 2nd Edn., Columbia University Press, ISBN: 0231130899.
Rawls, J., 1997. The Idea of Public Reason Revisited. Hardvard University Press, ISBN: 0674005694, pp: 573-615.

Van Fraassen, B., 2002. The Empirical Stance. Yale University Press, ISBN: 0300103069. 